\title{
Factors that Influence Individuals to Become Murderers in Sri Lanka
}

\author{
Prof. M.W. Jayasundara \\ Department of Criminology and Criminal Justice, University of Sri Jayewardenepura, Sri Lanka
}

\begin{abstract}
In Sri Lanka death penalty had been in place since the times of the ancient kings and also under the colonial rulers as a means of preventing grave crimes including murder. From 1956 to 1959 and again after June 1976 death penalty was not carried out in Sri Lanka. However, the murder rate has declined from 7.6 to 2.4 even without the implementation of the death penalty. It is assumed that rather than the capital punishment for murder some other significant factors have contributed to a decline in the number of murders in the country. This study was conducted to identify the causes and motives that lead people to commit crime in Sri Lanka. Here the background of the offenders and the methods used for committing murder were solicited. The data were collected with regard to the 63 offenders selected from a random sample drawn from those convicted of murder and housed in Welikada prison in Sri Lanka. For the purpose of data collection semi-structure interview schedule and case study were utilized.
\end{abstract}

The study has revealed that low-income earners and less educated individuals mostly tend to commit murder over minor matters in their daily life. Among a considerable number of people engaged in farming, laboring, fishing etc. tend to commit murder over the matters that might appear relatively trivial to other people. Previous enmity, family disputes, land disputes and drunkenness have been the precipitating motives of these offenders. This study suggests that the creation of awareness and the dissemination of knowledge among the low educated and low-income categories can cause a positive change in their conduct towards a peaceful and law-abiding life.

Key words: Murder, Motive, Method, Disputes, Alcoholism, Enmity.

\section{INTRODUCTION}

$I^{n}$ $\mathrm{n}$ the history of mankind people are reported to have acted violently and responded with murder even for minor disputes. For example, in the $16^{\text {th }}$ century in Rome the crimes of violence were innumerable. There had been more man created murders than the number of natural deaths. In the $14^{\text {th }}$ century the murder rate was 44 per 100,000 in Rome and during the $13^{\text {th }}$ to $14^{\text {th }}$ century in Germany the murder rate had fluctuated from 20 and 65 per 100,000. Many causes had contributed to the growth of murder rate in Europe. Among them the habit of carrying arms, alcohol induced quarrels, lack of medical treatment, absence of effective police power and non-existence of an effective justice system were prominent (Wales and Hemmens, 2011).
Presently, murder rate is low in politically stable as well as wealthy democratic countries while the developing countries and countries with rapid socioeconomic and political changes show high murder rate. However, the advancement in technology and medical science, improvements in education and thinking patterns have paved the way for a change in the motives of murder and created a down truth tendency to commit murder and violent crimes. For example, in Sri Lanka, one can identify the changes in their motives in committing murder and also in the methods adopted for it.

From a criminological perspective, the most grievous crime against individual is murder. According to the law, killing a person by another is considered as a capital offence. Murder is defined as follow: "Murder is the unlawful killing of another human without any justification or valid excuse, especially the unlawful killing of another human with malicious forethought. This state of mind may, depending upon the jurisdiction, distinguish murder from other forms of unlawful homicide such as manslaughter" (Wikipedia). Oxford Advanced Learners' Dictionary defines the murder as "unlawful killing of a human being intentionally" (Hornby, 1989:815). According to the penal code of Sri Lanka, murder is identified as "If the act by which the death is caused is done with the intention of causing death is a murder" (p.294).

Further, in order to complete an action of murder in Sri Lanka the following factors should be present.

i. The intention of causing death.

ii. The intention of causing bodily injury which is likely to cause death or

iii. The knowledge of an act which is likely to cause death (293 of Penal code).

As punishment for murder the death penalty has been carried out since the times of ancient Kings up to 1976. During the period of 1956-1959 this penalty had temporally been abolished. After June 1976 death penalty was not carried out on any murderer who was convicted of murder (Hood, 1989:22). Though it is said that murder rate is lower when death penalty is in operation, the data present in Figure 1. Indicates that murder rate was lower in the years 1978-1981 and 2002-2005 and 2009 onwards. 
Figure 1. Murder Rates in Sri Lanka 1970 -2019

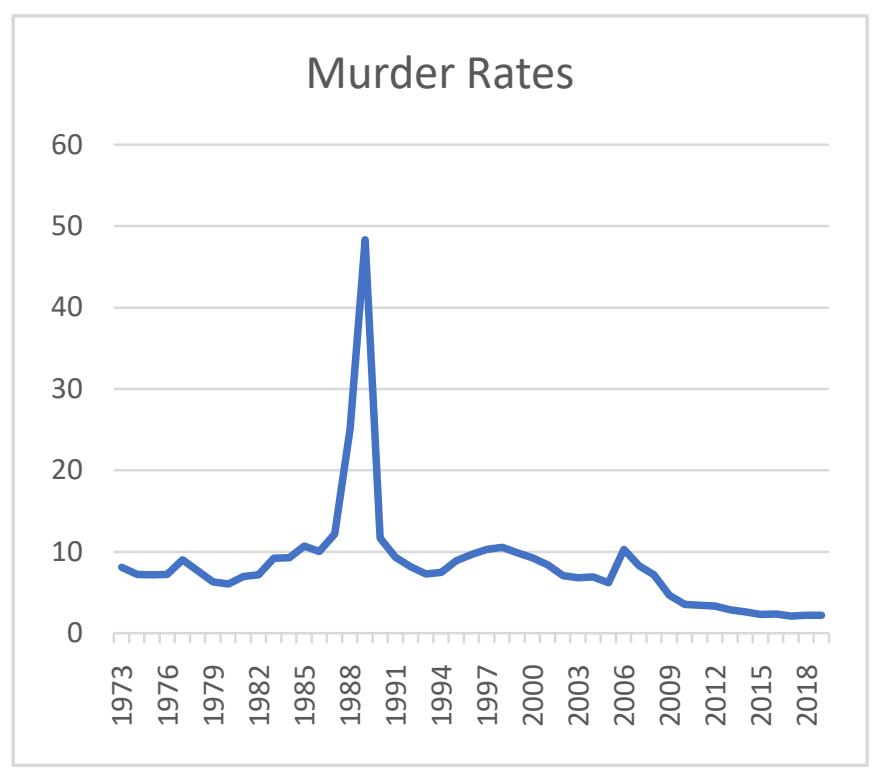

Source: Administration Reports of the Inspector General of Police 1973-2019

When death penalty is not implemented it is generally commuted to life imprisonment. For example, when death penalty was in operation in 1973 murder rate was 8.1 but after the death penalty was commuted to life imprisonment after 1976, murder rate declined to 2.2 in 2019.

\section{Research Problem}

In Sri Lanka, unlawful killing of people remained high until the recent decades. The death penalty for grievous crimes was practiced during the reigns of the kings in the country. But after the British colonization of the country the punishments were formalized and country's first penal code was introduced in 1883. Gradually, they replaced indigenous criminal justice with the British oriented criminal justice. The imposition of death penalty was limited to murder, treason and few other crimes. The sole purpose of penalty was to deter people committing crimes and keep them under the control of law and order introduced by the British. The death penalty had been in operation against the murder for several centuries except for its temporary abolition from 1956 to 1959. But death penalty has not been used since the 23 of June 1976 after hanging of the last person at Welikada Prison in Colombo, Sri Lanka. Although many criminologists and penologists believe that murder might go up in the absence of death penalty for murderers the reverse of it has taken place in Sri Lanka during the last two decades. But still people keep killing others due to various reasons. This study has focused its research problem as to why people commit murders and what sort of motives compelled them to kill others?

\section{Objectives}

- To identify the causes of murder in Sri Lanka.

- To identify the motives and the methods used in murder.
- To determine the nature of criminal behavior of the offenders.

\section{Significance of the study}

Though there had been some research conducted to examine the characteristics of homicides and the behavior of those who involved in homicides no research has been conducted previously in obtaining first-hand information through faceto-face interviews with the murderers. Therefore, this research will undoubtably be significant for both academics and the policy makers to work towards an extensive progression of crime prevention and policy planning. The research will also generate new knowledge as regards the criminal behavior of the murderers and the causes and the motives that led to commit such crime. Further, the information on the background of the offenders and the methods that they had used in committing murders were solicited.

\section{METHODS}

The study was carried out at Welikada prison in Colombo, Sri Lanka. This prison remains as the country's main prison which was built in 1844 under the British colonial administration. Though it has a capacity to detain 1100 prisoners, generally it houses over three thousand prisoners. For the present study, the prison inmates who have been imprisoned in Welikada prison for the offence of murder were taken as the population of the study.

The sample of the study

For the purpose of gaining a well-rounded picture of the criminal behavior of the offenders convicted of murder and also for finding the causes that they led to commit such offences including the motives of murder and the methods used for committing murder a random sample of 63 offenders were selected from a 300 population of convicted murderers housed in Welikada prison in Sri Lanka.

\section{Data Collection Methods}

The interviews were designed primarily to provide the offenders with the opportunity to reveal the causes that compelled them to commit murder and the circumstances associated with their criminal behavior. Questions relating to their background profiles as well as to the motives that made them commit such crimes were solicited. In addition to the interviews, case study methods were used for obtaining indepth information with reference to each respondent. This semi-structure open-ended procedure and case study procedure took approximately forty minutes per offender. However, the length of the interview was subject to a considerable individual variation. An assurance of confidentiality and a voluntary nature of participation were established with those who participated in the interviews.

In this study both qualitative and quantitative data were collected regarding the criminal behavior of the murderers. In analyzing data, standard data analysis methods were utilized to achieve the objectives of the study. 


\section{DATA ANALYSIS AND FINDINGS}

\section{Age Distribution of Murderers}

The present study was conducted on 63 individuals who had been punished with death penalty for committing the act of murder $(n=63)$. All respondents were males and their age groups are indicated in Table1.

Table. 1. Age distribution of the Offenders

\begin{tabular}{|c|c|c|}
\hline Age Group - years & Frequency & $\%$ \\
\hline $18-25$ & 04 & 6.3 \\
\hline $26-33$ & 26 & 41.3 \\
\hline $34-41$ & 13 & 20.6 \\
\hline $42-49$ & 12 & 19.0 \\
\hline $50-57$ & 06 & 9.5 \\
\hline Over 58 years & 02 & 3.2 \\
\hline Total & 63 & 100 \\
\hline
\end{tabular}

Source: Field Research 2019

According to the age distribution of the murderers the highest number of them belongs to the age group of 26-33 years. But the second and the third highest number represent the age groups between 42-49 and 34-41 age categories. The lowest number of individuals comprises the age group over 58 of years.

\section{Race}

Among the individualistic factors that affect murders, race was a significant factor for it uncovers cultural characteristics of the murderers. Figure 2 indicates that the highest number $(\mathrm{n}=58 ; 89 \%)$ represents the Sinhalese while the lowest number depicts the Tamils $(\mathrm{n}=3 ; 5 \%)$ and this number is equal to that of the Muslims.

Figure 2: Racial Distribution of Murderers

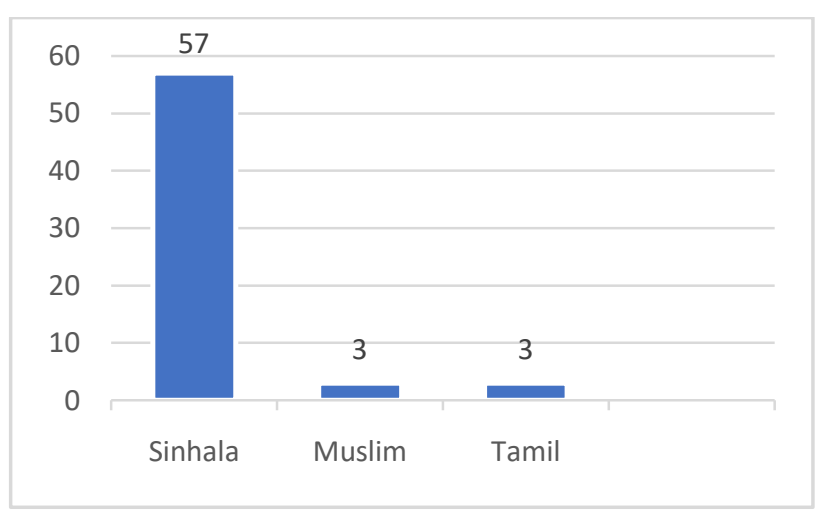

Source - Field Research, 2019

\section{Educational Level of the Murderers}

Table 2 indicates the level of education of the criminals who have committed murders. The low standard of education of the criminals reveals that there is a correlation between low education and murder. Accordingly, the majority of murderers $(\mathrm{n}=48 ; 76.1 \%)$ do not have the Ordinary Level educational qualification. Among them there were $6.4 \%(n=4)$ who had never been to school while $30.2 \%$ had studied up to grade 5 level.

Table 2: Educational Level of the Murderers

\begin{tabular}{|c|c|c|}
\hline Education Level & Frequency & $\%$ \\
\hline No Schooling & 4 & 6.4 \\
\hline Grade 1-5 & 19 & 30.2 \\
\hline $\begin{array}{c}\text { Grade 5 - Ordinary } \\
\text { Level }\end{array}$ & 25 & 39.6 \\
\hline Pass Ordinary Level & 9 & 14.3 \\
\hline Pass Advanced Level & 6 & 9.5 \\
\hline Total & 63 & 100 \\
\hline
\end{tabular}

Source - Field Research, 2019

Only $23.8 \%(n=15)$ of the sample had either G.C.E. or Advanced Level education. When the impact of education on crime is considered lower level of education often contributes higher crime rates of any society as the lack of education creates a society with poverty, unemployment, and inadequate health facilities. These factors have a direct bearing on deviant behavior patterns. Further, a society consists of educated people is an asset to individual himself as well as to the entire community for they bring about wealth, health, knowledge, skills and peace to the living environment. Lack of access to education paves the way for poverty. Therefore, it can be determined that the uneducated in the community disrupt the peaceful environment by behaving in a socially unaccepted manner and committing crime against the whole society.

\section{Civil Status of Offenders}

According to Figure 3, the status of family can be interpreted from their civil status. In the present study $41(65 \%)$ of the convicted offenders were married while $22(35 \%)$ remained unmarried. Some offenders had got married once they were bailed out at the court after arresting for murder.

Figure 3: Civil Status of Offenders

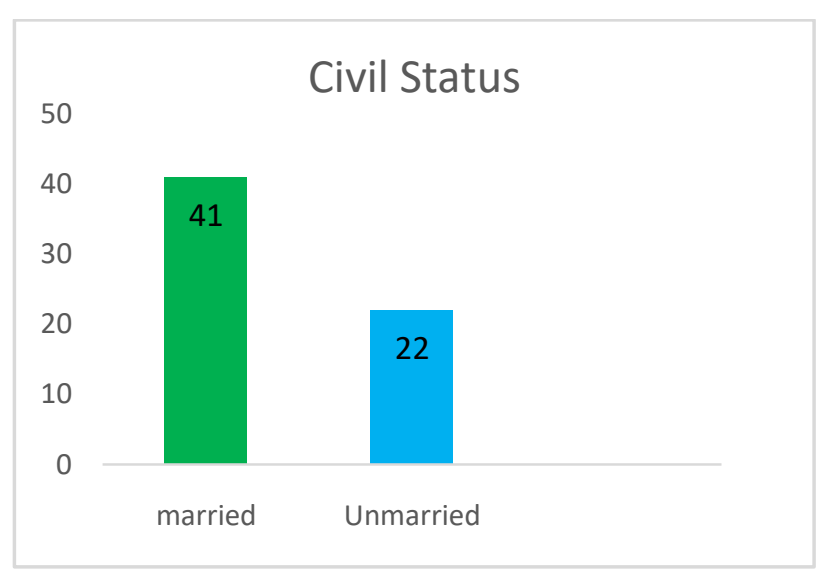

Source - Field Research, 2019 
The reason was that in some cases it had taken such a long time as over ten years to end their trial at court. During that period the offenders were on bail and they had entered the married life. However, two wives of the offenders had become separated from their husband and lived at their parental house.

\section{Family Status of the Offenders}

Figure 4 indicates the number of offenders who have children in their families and those who do not have children in their families. Accordingly, 39 (62\%) offenders had children in their families while 22 (34.9\%) offenders had no children as they were unmarried. But one offender $(3.1 \%)$ did not state whether he had any children while another offender stated he did not have any children until he was convicted and imprisoned for murder.

Figure 4. Children in the Family of Offenders

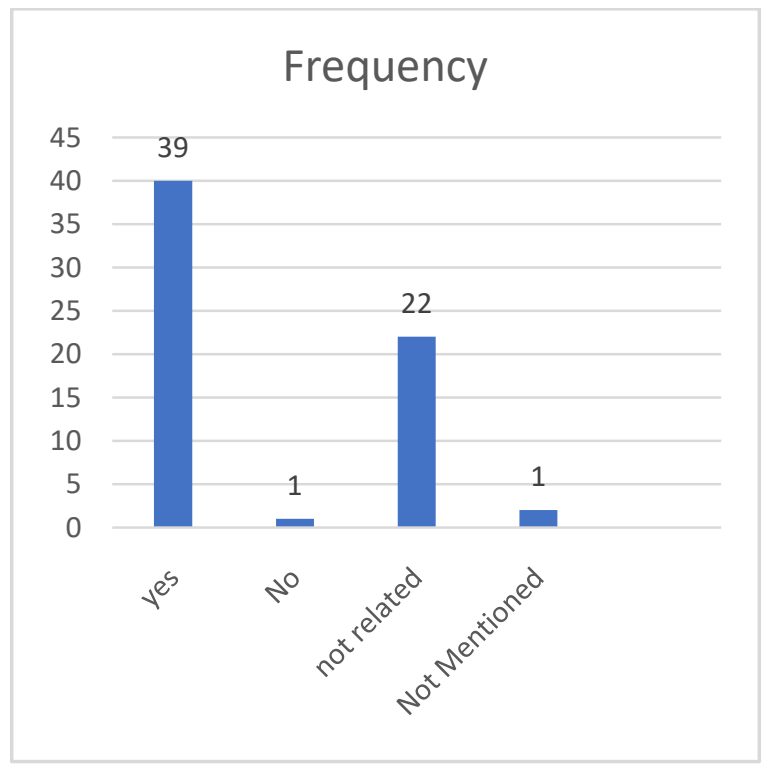

Source - Field Research, 2019

\section{Murderers' Relationship with their Parents}

The family background of the murderers was a main concern in this research. Figure 5 shows murderers' relationship with their parents and whether their parents were alive or not. Accordingly, the parents of $24(38 \%)$ offenders were alive whereas both parents of $16(25.3 \%)$ were dead. Of the rest of the offenders $6(9.5 \%)$ had only their father alive while 17 $(27 \%)$ offenders had their mother alive.Those who had both parents or a single parent had visited them in prison occationally while some parents were said to have not visited their sons at prison at all.
Figure 5: Parents' Living Status

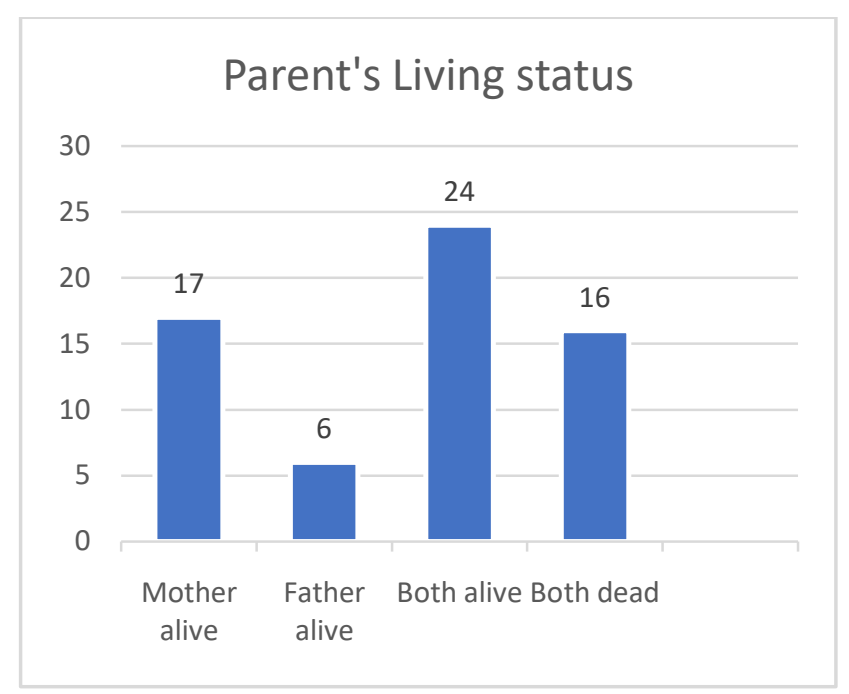

Source - Field Research, 2019

\section{Previous Occupation of the Offenders}

Occupations of the offenders before they were convicted were also a concern of this study. Accordingly, the offenders in the sample showed that they had different vocational backgrounds. Many convicted offenders $(n=18)$ had worked as farmers and the second highest number of them $(n=9)$ had worked as laborers. There were six army officers including the home guards who were involved in committing murder and five businessmen who had been accomplices in committing murder. There were four fishermen among the offenders who were convicted of murder. In addition, three convicted murderers had worked as salesmen and several other offenders were engaged in different employments as indicated in Figure 6.

Figure 6: Occupation of Offenders before the Conviction

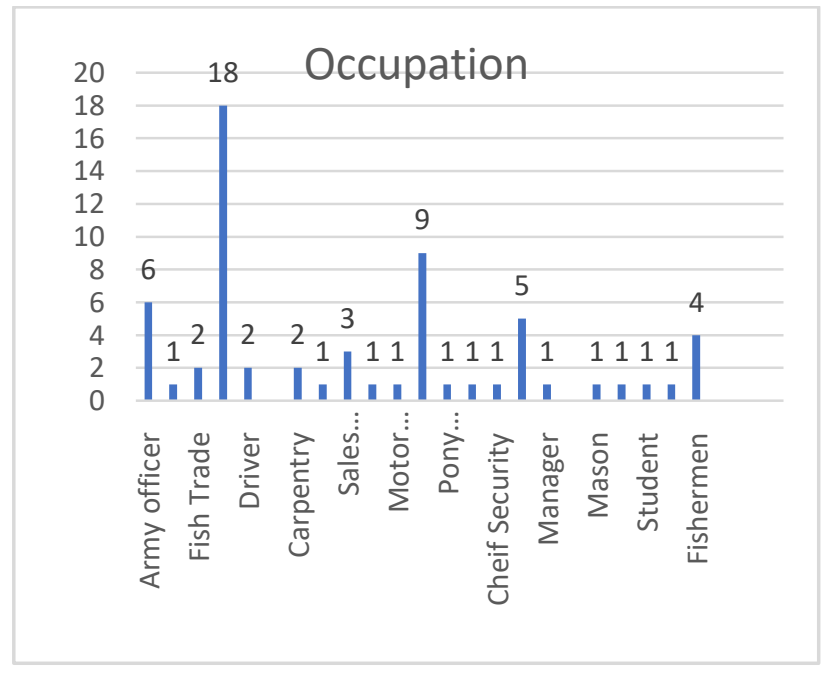

Source - Field Research, 2019 


\section{Criminality of the Offenders}

In the sample of the study, there were 63 offenders who had committed murder. Of them three had entered the victim's premises with the intention of committing either burglary or rape but the

Figure 7: Criminality of the Murderers

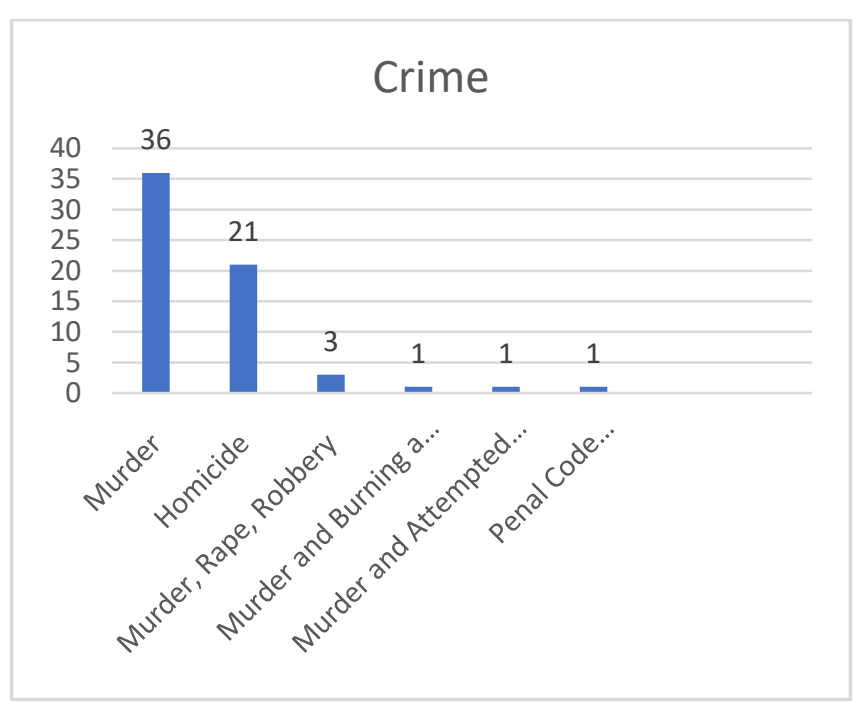

Source - Field Research, 2019

Unexpected behavior of the victim and the unforeseen circumstances had driven them to commit murder at the end. The majority of murderers had been convicted of murder and homicide and they had been charged according to the different sections of the Sri Lanka Penal Code as indicated in the Figure 7.

It is a common phenomenon that criminals begin their criminal career with minor crimes and later they proceed to commit grievous crimes. On the contrary, the present study reveals that only four out of 63 offenders carried previous criminal charges. Those four offenders had been imprisoned previously for committing other crimes. The rest $(n=59)$ did not have any previous conviction and they had lived as law abiding citizens before they committed murder as the first offence in their life.

Table 3. Motives of Murder

\begin{tabular}{|c|c|c|}
\hline Motives & Frequency & $\%$ \\
\hline Previous Enmity & 24 & 38 \\
\hline Dispute & 02 & 3.2 \\
\hline Family Dispute & 13 & 20.6 \\
\hline Land Dispute & 07 & 11.1 \\
\hline Drunkenness & 08 & 12.7 \\
\hline Commission of Other Crime & 03 & 4.8 \\
\hline Sudden Provocation & 02 & 3.2 \\
\hline Drunken brawl & 02 & 3.2 \\
\hline Unrequired Passion & 01 & 1.6 \\
\hline
\end{tabular}

\begin{tabular}{|c|c|c|}
\hline Paranoid Fears & 01 & 1.6 \\
\hline Total & 63 & 100 \\
\hline
\end{tabular}

Source - Field Research, 2019

The causation of crime against humans takes place due to various reasons. As a social animal an individual interacts with the other members of the society and especially with the people in his community. When he encounters unbearable situations or disagreeable occasions he tend to

react with violence under provocation and this scenerio leads to him to resort to criminal acts such as murdering and grievous hurt against the people they interact with. In other words, people do not kill their close relatives or other members merely for pleasure or without any provocative reasons. Therefore, the researchers and criminal justice officials have identified different reasons that people tempted to muder others. Among them different kind of disputes including land disputes, family disputes and other issues such as alcholism, drug addiction, illiteracy, irreligiousness, unemployment, poverty, political reasons. Sometimes, to a certain extent one can identify one or several reasons contributes to a murder. But the reasons that people tend to commit murder may vary from culture to culture or country to country. The present study has identified several causes which led the people in the sample to commit murder. As Table 3 indicates the most common motives for offenders to commit muders were previous enimity $(n=23)$, family disputes $(n=13)$, drunkenness $(n=7)$ and land disputes $(n=6)$. In addition, commision of other crimes such as rape and burglary had ended up with murder. Further, with reference to the present study, drunken brawl, sudden provacation and other types of disputes had been significant motives for committing murder.

Table 4. Weapons Used for the Murder

\begin{tabular}{|c|c|c|}
\hline Weapons & Frequency & $\%$ \\
\hline Pointed Knife & 31 & 49.2 \\
\hline Cutting Instruments & 08 & 12.7 \\
\hline Clubs & 04 & 6.3 \\
\hline Blunt Instruments & 01 & 1.6 \\
\hline Shot Guns & 12 & 19 \\
\hline Explosives & 01 & 1.6 \\
\hline Iron rod & 04 & 6.3 \\
\hline Strangulation & 01 & 1.6 \\
\hline Beating & 01 & 1.6 \\
\hline Total & 63 & 100 \\
\hline
\end{tabular}

Source - Field Research, 2019

Table 4. shows the type of weapons that has been used for murder. Considering all the weapons used the greatest contribution has been made by the pointed knifes (49.2\%). Since the last century onwards Sri Lankan people have used kinves for agricultural and other domestic purposes (Rogers, 1987:133). In Sri Lanka, the use of guns and other automatic 
weapons has been prescribed as an offence. Therefore, people use the pointed knife as a weapon for their protection and they usually carry knives when they move into agricultural areas or woods. When people in agricultural areas quarrel over disputes they often used a pointed knife to stab the enemy. In oder to prevent the use of knives during the colonial rule a special law was introduced in 1806 and also in 1906 (Dangerous Knives Ordinance, 1906). In the twentieth century H.L. Dowbiggin, a long-serving Inspector-General of Police in Sri Lanka, was of the view that fighting was everywhere in any society and it was inevitable. Therefore, his main concern was to reduce the use of knives at quarrels which led to murder committed by males of Sri Lanka. With that particular motive in his mind he had introduced boxing at schools to be used by males in fighting with others but his effort had not been successful (Rogers, 1987:144). This study reveals that people in Sri Lanka still use pointed knives as a means of mudering others. In addition, agricultural instruments such as cutting instruments $(12.7 \%)$, clubs $(6.3 \%)$ and blunt instruments $(1.6 \%)$ are used for committing murder. With the development of technology and the increase in organized crimes in Sri Lanka, people have begun to use illegal guns and pistols to commit different types of crimes and the present study reveals that 12 murderers $(19 \%)$ had used shot guns for killing others. Scholars have found out that the availability of guns contributed to an increse in homicide rates (Barlow, 1976:116). The chances of dying from gunshot wounds are said to be higher than in the other common methods used for killing such as stabbing with knives or tearing the victims with other cutting instruments. In the past murderers used the methods such as strangulation, poisioning, and beating to a higher extent but presently those methods are used to a lesser extent.

Figure 8: Punishment of Murderers

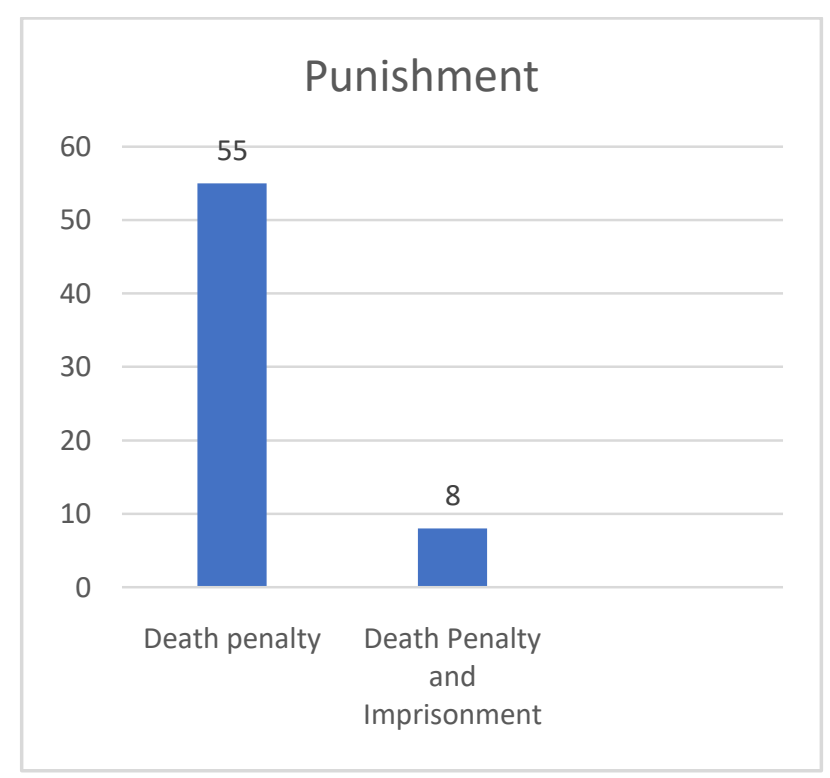

Source - Field Research, 2019
The above Figure 8 shows that the punishments given for convicted murderers for muder. Accordingly, 55 offenders $(87.3 \%)$ were setenced with death. They were ordered to be hung subject to the approval of the President of Sri Lanka. But it is noteworthy here that after 23 June 1976 death penalty was not carried out in Sri Lanka. Instead, those who have been convicted with muder and to be hanged now serve as commuted sentence of life imprisonment. Further, some offnders are granted life imprisonment after considering their crimes and behavior in prisons by an appointed board of officials. In the present study, it was found out that the death penalty meted out by the ministry of justice to eight (12.7\%) offnders had been mitigated to life imprisonment. However, those who are sentenced to life imprisonmnet have oppertunities to be released after the mitigation of their prison sentence upon careful consideration of their behavior in prison but theose who are punished with death are not entiteled to this previledge.

\section{Case Study 1.}

Wickramanayaka was born and bred in Kaduruwela, Polonnaruwa and presently he is 63 years old. He has studied up to grade 5 at a school located in Kaduruwela. He earned his livelihood by working as a mason and used to consume alcohol when an opportunity arrived. He was married and a father of two sons. He has migrated to Rajagiriya in Colombo in 1977 with his family and lived there until this murder occurred.

The victim was a woman and a neighbor of Wickramanayaka residing 200 meters away from his house. Victim's husband was in abroad when this incident took place. As murderer explains the incident "victim had a quarrel with my wife as victim did not return the money collected as a 'sittu'. Further the victim had become offended with me as I did not support the construction of her house though she wanted me to. The Victim used to insult me by calling 'ponnaya' when I was at home. When my wife went to the shop she was also insulted calling "always breakdown". My wife would often cry remembering insulting remarks made by the victim. Even the victim's children insulted me by calling "ponnaya". One day when I was returning from the town I happened to meet the victim and her daughter who were going to town. When I was just passing her, she called me "ponnaya" which provoked me to return home with great anger. I felt like assaulting her immediately. Then I picked up a knife and went back to the town and waited on her way back home. Soon I followed her and stabbed her right on her back of chest. I did not really intend to kill her, I just wanted to injure her and teach her a lesson for insulting me and my wife. However, at the end he was given death sentence for the murder that he had committed. He said he was repenting over the crime he had committed.

\section{Case Study 2.}

Jayantha is a 52-year-old laborer who lived in Somapura, Seruwawila. He had schooling up to grade four. His mother 
had died and father had remarried. Jayantha was married but had no children. After two years of marriage he became separated from his wife as the wife had an affair with a person named Sunil. His step mother had a 14-year-old school girl called Shyamali. On the day of this incident (19.05.1999) the victim had returned home from school and it was around 3.00 p.m. when Jayantha returned after fishing in the tank. He had inquired about his identity card given to Shyamali to be kept in a protective place. Then Shayamali had replied that the identity card was not in the place where she kept it. Then Jayantha had got flared up and chopped her head by giving three blows at her with a curved knife thus causing the death of Shyamali on the spot. After the incident he had been arrested and prosecuted for committing murder. Consequently, he was sentenced to death in 2012.

\section{Case Study 3.}

Siripala is a 67-year old timber worker who lived in Passara area in Uva province. He was married to a woman in Kegalle and had three children. On the day of this incident his wife had deserted him together with her three children and lived at her parental house. As he said he was on suspended sentence for seven years for carrying a pistol given to him by Grama Sevaka in the area. Siripala had come to see his wife and children to Kegalle and proposed her wife to go back with him to his house in Passara but the wife refused it. Then he left his wife's house to go to Passara and on his way he met a person about 55 years old in Kandy called Piyasena who himself introduced as a sorcerer. The sorcerer had inquired about the situation of Siripala and had promised him getting back his wife and children within seven hours by using his sorcery power. After making agreement with the sorcerer Siripala had accompanied him to his house in Passara and had consumed alcohol heavily both of them.

After the lapsed of days Piyasena did not succeed in getting back Siripala's wife to his house. Siripala had spent around five thousand rupees for liquor and food. On the fourth day sorcerer got ready to leave Siripala's house secretly without executing his promise. Then Siripala had become furious and hit the Sorcerer's head with an iron rod and killed him. When this incident occurred both Siripala and the Sorcerer had consumed alcohol heavily and he was not aware of the action carried out. After being convicted for murder Siripala had been sentenced to death.

The case studies mentioned above indicated that all those incidents had happened due to some minor disputes and heavy consumption of alcohol. In the case study 1 , the perpetrator was provoked by a minor dispute and the ignorance of the victim has caused her death. In the case study 2 , the perpetrator was made extremely angry by the response given of his sister and with as thoughts he had killed her under provocation. In the case study 3 , both perpetrator and the victim had believed in super natural powers and it was their ignorance and belief in such powers that brought about the death of the sorcerer in existence. There is an established association between alcohol consumption and violent crimes (Vaughn, 2009: 179). It is believed that there exists a causal relationship in many instances between alcohol and murder (Wolfgang, 1958:136). In the case study 3, that shows the behavior of both the perpetrator and the victim was a direct result of the excessive consumption of alcohol.

\section{CONCLUSIONS}

This study was aimed at conducting research on the criminal behavior of individuals convicted of murder and the causes that led to commit such an offence. Accordingly, data were gathered and analyzed in line with the objectives of the study. The following conclusions were drawn from the study.

As the age groups are concerned of the sample of the study the highest number $26(41.3 \%)$ of offenders represent the 2633 age group and the second highest number 13 (20.6\%) offenders belong to the 34-41 age group. The third highest category of the offenders $12(19 \%)$ represents the age group of 42-49 years. However, no offenders were identified under the age of 18 years.

According to the ethnic factor of the offenders, the highest numbers of murderers 57 were Sinhalese, while Tamils and Muslims included three murderers in each group respectively. As the educational levels are concerned there is a direct relationship between less education and the commission of murder. Accordingly, $6.4 \%$ of the offenders had never attended school while $30.2 \%$ had attended only up to grade 5 in the school. As a whole $76.2 \%$ had received education below Grade 11 while the rest had passed grade 11 or received higher education up to Advanced Level. The education brings up desirable change in the behavior of mankind together with knowledge, skills and understanding in one's life. In addition, education develops human personality, thoughts and amiable relationships. However, the uneducated and the less educated do not often find success in their lives as compared to the educated. Hence, they are mere inclined to find avenues for illegal activities.

The civil status of the offenders indicated that $42(67 \%)$ of them were married and of them $39(62 \%)$ had 1-4 children in their family whereas $21(33.3 \%)$ offenders remained unmarried.

The previous occupation of offenders was another concern in the study. The highest number of offenders $(n=18)$ had worked as farmers in their locality. There were 9 laborers, 6 fishermen, 6 army personal and 5 businessmen within the group of the offenders. Accordingly, it was revealed that these people had lived mostly in rural areas and more murders had taken place in rural areas as compared to the urban areas.

When the criminality of offenders was considered only 3 of them had committed other crimes such as rape and robbery of which the end result was the murder. The rest 60 offenders were directly involved in murder. Among the offenders 59 had committed murder as the first crime of their lifetime and 
they had not been subject to any previous conviction and only four offenders had previous convictions.

The motives of murderers for killing others were main concerns in the study. Accordingly, the highest number $(n=24)$ of murderers had previous enmity as a motivating factor to commit murder. It is assured that people harbor grudges against others over dispute and when the time is ripe they avenge on their enemies. Family disputes $(n=13)$ and land disputes $(n=7)$ were other prominent motives of the offenders for murder. As the unresolvable disputes surface among family members such as between parents, parents and siblings and among siblings themselves the end result was the murder of a family member. Land disputes have remained as a principal motive for murder for a long period among Sri Lankans but at present this factor has declined up to $11.1 \%$ as compared with other motives. The effectiveness of the criminal justice and the introduction of Conciliatory Boards in the country may have contributed to the decline of land disputes as the principal motive for murder. The alcoholism has also contributed as a motivating factor to commit murder for a long period of time in the annals of crime in Sri Lanka and it still prevails to a lesser degree in the country. When a person kills another alcoholism often appears to be as a predominant factor. Sometimes, it is one of several compilatory factors.

As the methods of committing murder are concerned pointed knives have been exclusively used and their rate stands of $49.2 \%$. In addition, cutting instruments $12.7 \%$, clubs $6.3 \%$ and iron rods were prominently used while traditional methods such as poisoning, strangulation and beating have become atrophied. Instead with the development of technology illegal guns have been increasingly used by organized criminal gangs as a method of committing murder. The hand guns are available at exorbitant prices in the illegal market though the government has made severe restrictions in gun acquisition and ownership by imposing severe penalties.

\section{REFERENCES}

[1] Administration Reports of Inspector General of Police (19742016) Sri Lanka.

[2] Barlow H.D. (1978) Introduction to Criminology. USA: Little, Brown and Company

[3] Dangerous Knives Ordinance, No. 28 of 1906.

[4] Hood, R. (1989) The Death Penalty. Oxford: Oxford University of Press

[5] Hornby, A.S. (1989) Oxford Advanced Learner's Dictionary. Oxford: Oxford University Press.

[6] Jayewardene, C.H.S. and Ranasinghe, H. (1963) Criminal Homicide in the Southern Province. Colombo: Apothecaries Co., Limited

[7] Rogers J.D. (1987) Crime Justice and Society in Colonial Sri Lanka. The United Kingdom: Curzon Press

[8] Vaughn M.G. (2009) Biosocial Criminology New Directions in Theory and Practice. Ed. Walsh A., Beaver K.M., New York: Routledge.

[9] Walsh, A., Hemmens, C. (2011) Introduction to Criminology. USA: Sage Publication In cooperation.

[10] Wikipedia.org/wiki/Murder. retrieved February 2, 2021

[11] Wolfgang, M. (1958) Patterns in Criminal Homicide. Philadelphia: University of Pennsylvania Press. 